PACS numbers: 85.35.Be, 73.22. - f.

УДК 621.317; 538.9

\title{
C-V AND AS STUDY OF SELF-ASSEMBLED GE ISLANDS IN SI P-N JUNCTION
}

\author{
M. V. Shkil, V. V. Ilchenko, O. V. Tretyak, P. S. Chen ${ }^{1}$, Z. W. Pei ${ }^{1}$, M. J. Tsai ${ }^{1}$ \\ Kyiv National Taras Shevchenko University, 64,Volodymyrska str., Kyiv, Ukraine 01033 \\ ${ }^{1}$ Industrial Technology Research Institute, ERSO/ITRI Bldg.15,195-4,Sec.4, Chung Hsing Rd., \\ Hsinchu, Taiwan 310, R.O.C
}

\section{Summary \\ C-V AND AS STUDY OF SELF-ASSEMBLED GE ISLANDS IN SI P-N JUNCTION}

M. V. Shkil, V. V. Ilchenko, O. V. Tretyak, P. S. Chen, Z. W. Pei, M. J. Tsai

The electrical properties of self-assembled Ge quantum dots (QDs) and Ge quantum wells (QWs) embedded in Si p-i-n diodes were studied using capacitance-voltage $(\mathrm{C}-\mathrm{V})$ measurements and admittance spectroscopy(AS). The investigated samples were grown on $\mathrm{Si}(001)$ substrates by an ultra high vacuum chemical vapour deposition (UHV-CVD) system. A linear increase of the thermal activation energy observed in voltage-dependent admittance spectroscopy(from $250 \mathrm{meV}$ up to $380 \mathrm{meV}$ ) for the sample with quantum dots shows that the ensemble of Ge islands has a low, continuous averaged density of states. For the sample without Boron pretreatment we found two levels with activation energies about $132 \mathrm{meV}$ and $202 \mathrm{meV}$ which were about constant in some reverse bias region.

Key-Words: Quantum dot, quantum well, admittance spectroscopy, activation energy.

\section{Анотація \\ ВОЛЬТ-ФАРАДНІ ВИМІРИ ТА СПЕКТРОСКОПІЯ ПРОВІДНОСТІ САМООРГАНІЗОВАНИХ ГЕРМАНІЕВИХ ОСТРІВЦІВ В КРЕМНІЄВИХ P-N З'СДНАННЯХ}

М. В. Шкіль, В. В. Ільченко, О. В. Третяк, П. Ш. Чен, З. В. Пей, М. І. Тсаі

За допомогою вольт-фарадних вимірів та спектроскопії провідності досліджувалися електричні властивості самоорганізованих германієвих квантових точок та квантових ям, що були вбудовані в кремнієві p-i-n діоди. Досліджувані зразки були вирощені на кремнієвій підкладинці з орієнтацією 001 за допомогою надвисоковакуумного хімічного парового осадження. Лінійний ріст термічної енергії активації (з 250 меВ до 380 меВ), який отримується після обробки даних спектроскопії провідності для зразку з квантовими точками, показує, що ансамбль германієвих острівців має малу за величиною та в середньому неперервну густину станів. Для зразку без попередньої обробки бором ми знайшли два рівня з енергіями активації біля 132 меВ та 202 меВ, значення яких майже не змінювалися в деякому діапазоні зворотніх напруг.

Ключові слова: Квантова точка, квантова яма, спектроскопія провідності, енергія активації. 


\title{
Аннотация \\ ВОЛЬТ-ФАРАДНЫЕ ИЗМЕРЕНИЯ И СПЕКТРОСКОПИЯ ПРОВОДИМОСТИ САМООРГАНИЗОВАННЫХ ГЕРМАНИЕВЫХ ОСТРОВКОВ В КРЕМНИЕВЫХ P-N СОЕДИНЕНИЯХ
}

\author{
Н. В. Шкиль, В. В. Ильченко, О. В. Третьяк, П. Ш. Чен, З. В. Пей, М. И. Тсаи
}

\begin{abstract}
С помощью вольт-фарадных измерений и спектроскопии проводимости исследовались электрические свойства самоорганизованных германиевых квантовых точек и квантовых ям, встроенных в кремниевые p-i-n диоды. Исследуемые образцы были выращены на кремниевой подложке с ориентацией 001 с помощью сверхвысоковакуумного химического парового осаждения. Линейный рост термической энергии активации (с 250 мэВ до 380 мэВ), который получается после обработки данных спектроскопии проводимости для образца с квантовыми точками, показывает, что ансамбль германиевых островков имеет малую по величине и в среднем непрерывную плотность состояний. Для образца без предварительной обработки бором мы нашли два уровня с энергиями активации около 132 мэВ и 202 мэВ, значения которых не изменялись в некотором диапазоне обратных напряжений.
\end{abstract}

Ключевые слова: Квантовая точка, квантовая яма, спектроскопия проводимости, энергия активации.

Modern semiconductor technologies nowadays combine more than few tens of millions of transistors on a single chip, forming an intergrated circuit that is extremely complex and sophisticated. With the progress in semiconductor technologies, it can be expected that a single element in such circuits may be scaled down to a size of a few nanometers or a few tens of nanometers in the nearest future. However, a device of such small dimension represents new phenomena, leading to very different operation mechanisms as compared to those of conventional devices. In addition, the fabrication method of the small-size elements differs greatly from the large-scale integration technology of the conventional devices. Nanostructures based on the germanium-on-silicon heterosystem attract the attention of technologists owing to significant progress in the development of new quantum-effect devices. In recent years, the potential applications of the $\mathrm{Ge} / \mathrm{Si}$-based semiconductor materials containing the nanometersized Ge clusters(quantum dots) embedded in the Si matrix have become apparent.

Self-assembled quantum dots can be grown with high structural quality and relatively high homogeneity by molecular-beam epitaxy (MBE) or chemical vapour deposition (CVD). The unique optical and electrical properties of such quantum dots stimulated intense research activities, and some novel optoelectronic devices such as quantum-dot lasers, ${ }^{1}$ optical memory struc- ture, ${ }^{2-4}$ and lateral intersubband detectors ${ }^{5,6}$ have been demonstrated.

In this work, we present the results of an admittance spectroscopy study on medium-size Ge islands embedded in Si p-i-n diodes. The C-V measurements are also presented. We show that for one sample the activation energy obtained from the admittance measurements increases linearly with the applied bias and conclude that these islands on the average have a low, continuous density of states. Also we demonstrate that for other sample the activation energies remain constant with the applied bias and connect that with existence of the high carrier concentration in some regions of the structure.

The investigated samples were grown on $\mathrm{Si}(001)$ substrates by a commercial available ultra-high vacuum chemical vapor deposition (UHV-CVD) system. Pure SiH4 and $5 \% \mathrm{He}$-diluted $\mathrm{GeH} 4$ were used as the precursor gas. After depositing an 300-nm Si buffer layer on the substrate, five-fold stacks of $\mathrm{Ge} / \mathrm{Si}$ bilayers were then deposited at $600{ }^{\circ} \mathrm{C}$. Finally, the layer structures were completed by depositing 150-nm Si cap layer(Fig.1). After growth, the samples were processed into mesas with different area for C-V measurements. In this study, four samples with different $\mathrm{B}_{2} \mathrm{H}_{6}$ pretreatment before QD growth were grown.

In order to study the level scheme in the valence band of our samples, admittance measure- 
ments are performed. In these measurements, the $a c$ conductance and capacitance of the sample are measured as a function of temperature for various fixed external bias voltages.

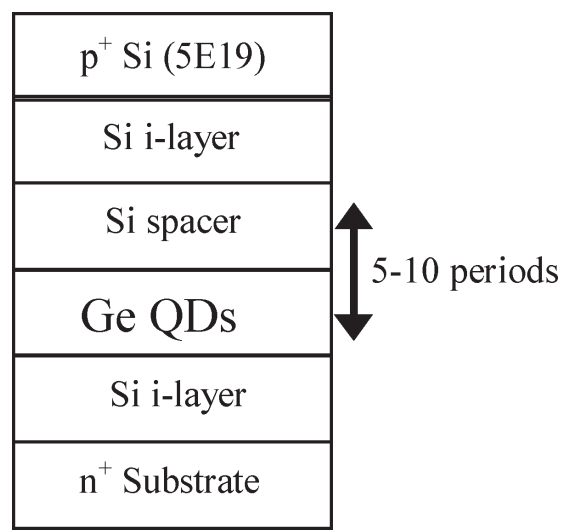

Fig.1. Schematic picture of the p-i-n diode layer geometry used.

In principle, the quantum dots can be generally considered as carrier traps, so that the analysis of quantum dot admittance spectroscopy will be similar to that of defects in bulk semiconductors. For a dot layer embedded in the p-type region of a space-charge structure, approximate equivalent circuit for junction admittance can be considered as a quantum dot charging capacitance $\mathrm{C}_{\mathrm{d}}$ in series with a charging resistance $R_{d}$, and then in parallel with a depletion capacitance $\mathrm{C}_{0}$ representing the free-electron contribution(Fig. 2).

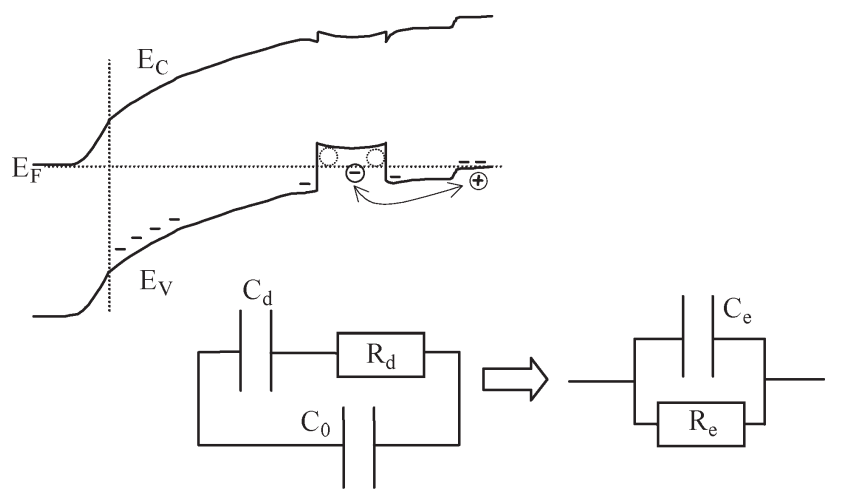

Fig.2. Schematic band structure and equivalent circuit model for describing a dot layer embedded in the $\mathrm{p}-\mathrm{i}-\mathrm{n}$ diode.

When a test signal of angular frequency $w$ $(w=2 \mathrm{p} f)$ is applied, under the parallel measurement mode, the equivalent conductance $\mathrm{G}_{\mathrm{p}}$ and capacitance $\mathrm{C}_{\mathrm{p}}$ seen by the capacitance meter are given by,

$$
\begin{gathered}
C_{e}(w, T)=C_{0}+\frac{C_{d}}{1+w^{2} \tau(T)^{2}}, \\
G_{e}(w, T)=C_{d} \frac{w^{2} \tau(T)}{1+w^{2} \tau(T)^{2}},
\end{gathered}
$$

where $\tau(T)=R_{d} C_{d}=\frac{1}{\sigma \cdot b \cdot T^{2}} \exp \left(\frac{E-E_{V}}{k T}\right)$.

As shown in Fig.2, when the Fermi level intersects with the dot level, the applied ac voltage will cause an alternate filling and emptying of the dots.

Looking at AS data for the sample without Boron pretreatment(Fig.3) we can see that capacitance steps always occur at the same temperatures under different reverse bias voltages. The constant step position indicates a nearly constant Fermi energy and an effective screening of the electric field by the accumulated charge.

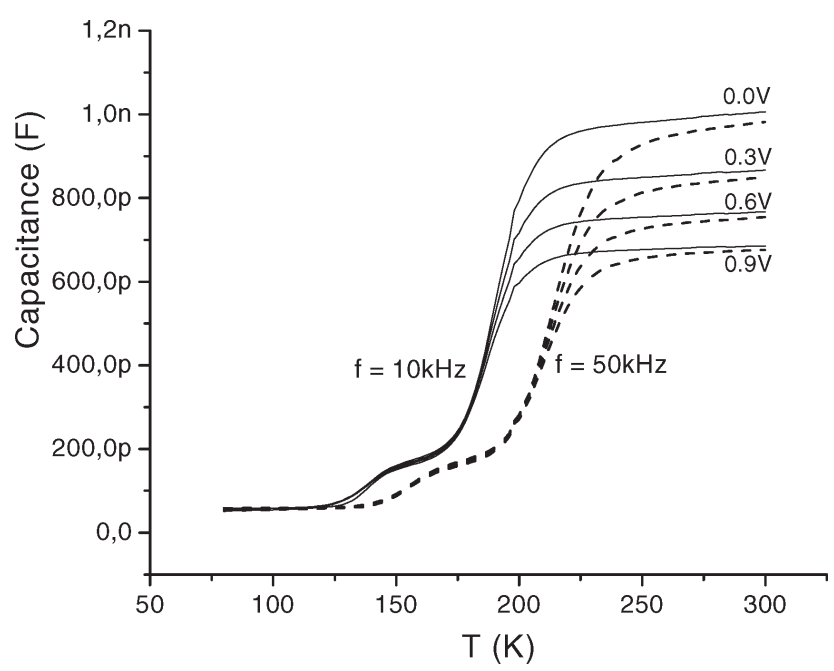

Fig.3. Admittance spectra of the sample without Boron pretreatment for measuring frequencies $10 \mathrm{kHz}$ and $50 \mathrm{kHz}$ at different bias conditions.

It is known from literature ${ }^{7}$ that according to a self-consistent band-structure calculation, the 6nm-thick $\mathrm{Si}_{0.7} \mathrm{Ge}_{0.3}$ quantum well has two confined states, a heavy-hole state with a localization energy of $197 \mathrm{meV}$ and a light-hole state with $128 \mathrm{meV}$.

From our AS data for the sample without Boron pretreatment (Fig.3) we have two levels with activation energies about $132 \mathrm{meV}$ and $202 \mathrm{meV}$. These activation energies are about constants in some reverse bias region. So it is most likely that our sample has quantum wells with the $202 \mathrm{meV}$ heavy-hole state and the light-hole state with $132 \mathrm{meV}$. 
The results of the $\mathrm{C}-\mathrm{V}$ measurements taken on the sample without Boron pretreatment are shown in Fig.4. On the C-V curves we can see a vast plateau that is evidence of the big carrier concentration in the investigated region. In one's turn this is in compliance with AS data. Also one can see that for higher reverse bias voltages the increasing leakage current of the diode inhibits accurate capacitance measurements.

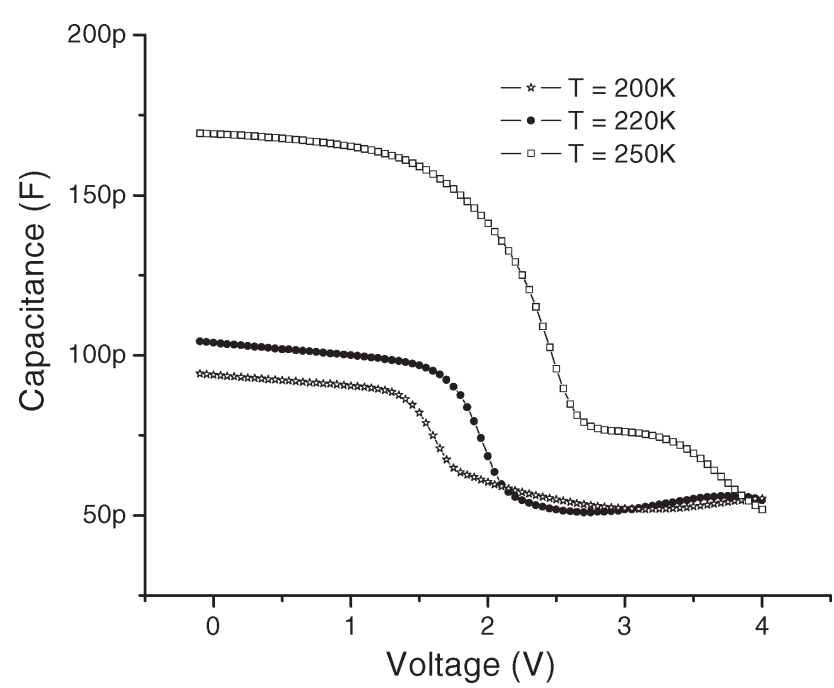

Fig.4. C-V curves at different temperatures for the sample without Boron pretreatment at a measuring frequency $1 \mathrm{MHz}$.

The AS measurements for the sample with high Boron pretreatment give a significantly different picture. With increasing reverse bias, the position of the capacitance steps shifts strongly towards higher temperatures(Fig.5).

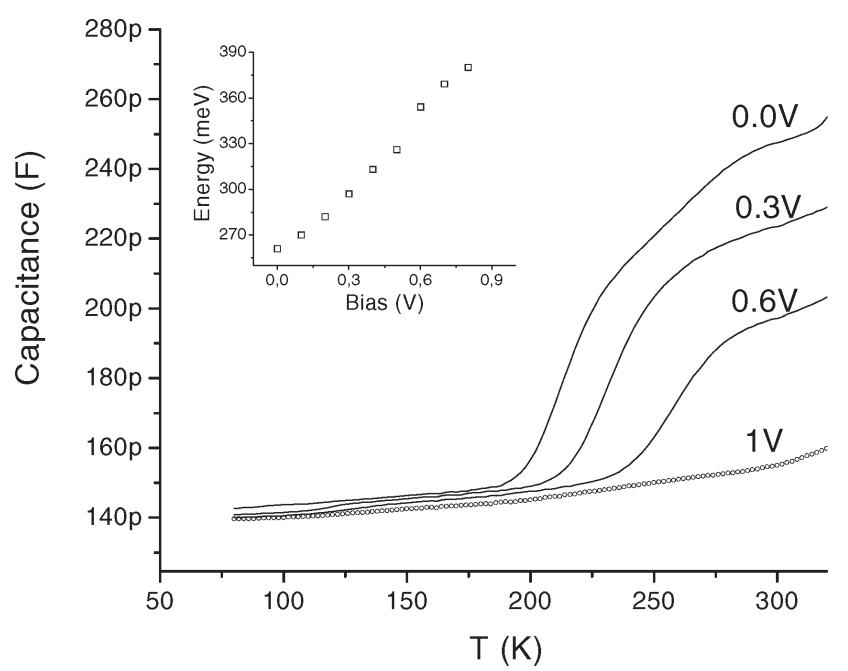

Fig.5. Admittance spectra of the sample with high Boron pretreatment for a measuring frequency $50 \mathrm{kHz}$ at different bias conditions. Inset: Arrhenius plot obtained from the admittance spectra.
For a bias voltage of $1 \mathrm{~V}$, the signal has completely vanished. This is consistent with the observation from the $\mathrm{C}-\mathrm{V}$ measurements(Fig.6). In the inset of Fig.5, the activation energies of the E1 peak for the sample with high Boron pretreatment are plotted as a function of reverse bias. With increasing bias voltages the activation energy increases up to a value of about $380 \mathrm{meV}$ at $0.8 \mathrm{~V}$ bias. We can ascribe this energy to the ground states of the islands since the signal vanishes for higher bias voltages.

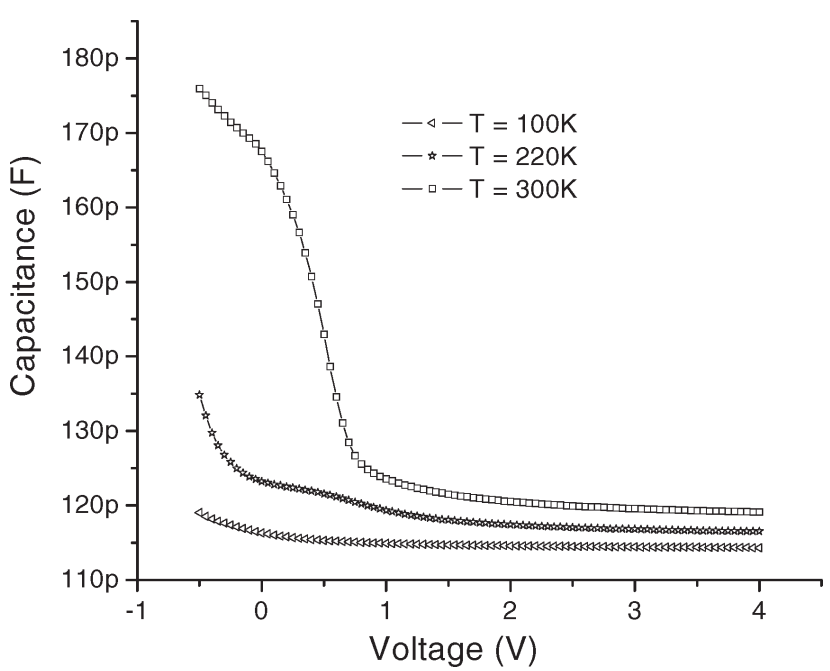

Fig.6. C-V curves at different temperatures for the sample with high Boron pretreatment at a measuring frequency $1 \mathrm{MHz}$.

In the bias range where the linear increase in the activation energy occurs, the behavior of the sample with high Boron pretreatment is different from that of the sample without Boron pretreatment.

Rational explanation is the low density of states tentatively causes the strong charge depletion and energy shift with bias voltage observed in the island structure(high Boron pretreatment) compared to the quantum-well sample(no Boron pretreatment).

In conclusion, we have investigated the electrical properties of the self-assembled Ge islands and quantum wells embedded in the p-i-n Si diode structures by means of the capacitance-voltage measurements and admittance spectroscopy. From the C-V measurements, it is obvious that the carrier concentration in quantum wells is remarkably larger than that in quantum dots. By admittance spectroscopy we can devide samples that have quantum well layers from ones that have quantum dots layers. The lack of the Boron 
pretreatment put obstacles in the way of the nucleation of the quantum dots. For the sample without Boron pretreatment the constant step position indicates a nearly constant Fermi energy and an effective screening of the electric field by the accumulated charge. For the sample with high Boron pretreatment the position of the capacitance steps shifts strongly towards higher temperatures with increasing reverse bias. The linear increase of the thermal activation energy observed in voltage-dependent admittance spectroscopy for the sample with quantum dots shows that the ensemble of Ge islands has a low, continuous averaged density of states. Such a peculiar density of states for islands could perhaps serve to design quantum-dot devices as, for example, lateral photodetectors where the absorption wavelength can be continuously tuned by a vertical gate.

\section{References}

1. Grundmann M. The present status of quantum dot lasers //Physica E (Amsterdam). — 2000. — № 5. P.167-184.

2. Imamura K., Sugiyama Y., Nakata Y., Muto Sh. and Yokohama N. New optical memory structure using self-assembled InAs quantum dots //Jpn. J.
Appl. Phys. - 1995. - Part 2, №34. - P.L1445L1447.

3. Yusa G. and Sakaki H. Trapping of photogenerated carriers by InAs quantum dots and persistent photoconductivity in novel GaAs/nAlGaAs field-effect transistor stuctures //Appl. Phys. Lett. — 1997. — №70, P.345-348.

4. Finley J. J., Skalitz M., Arzberger M., Zrenner A., Bohm G. and Abstreiter G. Electrical detection of optically induced charge storage in self-assembled InAs quantum dots //Appl. Phys. Lett. - 1998. №73, P.2618-2620.

5. Lee S. W., Hirakawa K. and Shimada Y. Bound-tocontinuum intersubband photoconductivity of selfassembled InAs quantum dots in modulationdoped heterostructures //Appl. Phys. Lett. -1999. — №75. - P.1428-1430.

6. Chu L., Zrenner A., Bohm G. and Abstreiter G. Lateral intersubband photocurrent spectroscopy on InAs/GaAs quantum dots //Appl. Phys. Lett. 2000. - №76, P.1944-1946.

7. Miesner C., Asperger T., Brunner K. and Abstreiter G. Capacitance-voltage and admittance spectroscopy of self-assembled $\mathrm{Ge}$ islands in $\mathrm{Si} / /$ Appl. Phys. Lett. -2000. — №77, P.2704-2706.

8. Chang W.H., Chen W.Y., Chou A.T., Hsu T.M., Chen P.S., Pei Z.W. and Lai L.S. Effects of spacer thickness on optical properties of stacked $\mathrm{Ge} / \mathrm{Si}$ quantum dots grown by chemical vapor deposition //J. Appl. Phys. -2003. — №93, P.4999-5002. 